Arab Univ. J. Agric. Sci., Ain Shams Univ., Cairo, 14(1), 381-394, 2006

\title{
UTILIZATION OF COMBINING BIOTIC AND ABIOTIC TREATMENTS TO CONTROL BACTERIAL ANGULAR LEAF SPOT DISEASE OF CUCUMBER
}

[25]

\author{
Abd El-Sayed ${ }^{1}$, M. Wafaa; E.A.M. Gado ${ }^{1}$; N.Y. Abd El-Ghafar ${ }^{1}$
}

\begin{abstract}
Bacterial angular leaf spot disease caused by Pseudomonas syringae pv. lachrymans is an important foliage disease of cucumber, under protected cultivation system. The present work was planned to control the disease using bio-agents and abiotic agents alone or combining, under greenhouse and commercial plastic house conditions. Data obtained indicated that application of bio- and abiotic agents decreased severity of bacterial angular leaf spot disease of cucumber, compared with the control. Fluorescent Pseudomonads (Pseudomonas aeruginosa, P. fluorescens and $P$. putida isolates) were more effectiveness than isolate of Bacillus subtilis to reduce the disease severity, when they were applied as soil drench treatment. Application of abiotic agents as foliar treatment was more effective than as seed treatment to decrease the disease severity. Isolates of $P$. fluorescens or $P$. putida as bio-agents and salicylic acid or ethephone as abiotic agents were the most effective against the disease. Disease severity was significantly reduced by increasing rates of abiotic agents. However, interaction between bio-agents (P. fluorescens or P. putida isolates) as soil treatment and abiotic agents (salicylic acid or ethephone) as foliar treatment greatly decreased severity of bacterial angular leaf spot disease of cucumber, under greenhouse and commercial plastic house condition, compared with the control. Combination between $P$ fluorescens isolate as soil treatment and salicylic acid as foliar treatment were the most effective against the disease.
\end{abstract}

Keywords: Bacterial angular leaf spot, Cucumber, Pseudomonads syringae pv. lachrymans, Bio-agents, Abiotic agents

\section{INTRODUCTION}

Bacterial angular leaf spot caused by $P$. syringae pv. lachrymans (Smith and Brain) Yang et al is a worldwide and destructive to cucumber. The bacterium attacks cucumber (Cucumis sativus) grown under field conditions in humid and semi-humid climates (Dixon, 1981). Biological control of plant diseases by microbial agents has been extensively investigated during the past decades

1- Department of Plant Pathology, Faculty of Agriculture, Ain Shams University, Shobra, El-Khema, Cairo, Egypt.

(Received September 27, 2005)

(Accepted November 7, 2005) 
(Weller, 1988 and Schroth et al 1984). Palleroni (1984) observed that fluorescent Pseudomonads usually coexists with other microorganisms in diverse environments including soil, water and biomaterials and reported as potential biocontrol agents of phytopathogens. Plant growth-promoting rhizobacteria (PGPR) strains were tested as seed treatments or foliage sprays for biological control against multiple cucumber pathogens under greenhouse and field conditions (Raupach and Kloepper, 1998) and were applied as seed treatment alone or as seed treatment plus as soil drench at transplanting against several diseases of cucumber (Liao, 1989). Mei et al (1990) applied application of some PGPR strains to foliage diseases. It was found that application of PGPR strains induces systemic resistance against cucumber diseases (Liao, 1989; Liu et al 1995 and Raupach and Kloepper, 2000).

Induction of systemic resistance became widespread in plant disease control (Kuc, 1987). Induced resistance is non specific, being an effective approach against a wide range of plant pathogens (Ye et al 1995). Abiotic inducer (salicylic acid and acetyl salicylic acid) showed positive results in controlling fungal diseases (Ye et al 1989), Viral diseases (Van Loon and Antoniw, 1982) and bacterial diseases (Rasmussen $\boldsymbol{e t}$ al 1991).Induced systemic resistance (ISR) can be induced in susceptible and resistant cultivars using pathogen, nonpathogen and certain chemical compounds (Madamanchi and Kuc, 1991 and Kuc and Strobel, 1992). Chemical inducers that have been reported include Oxalate, Di-basic phosphate, $\beta$-ionone, 2 , 6 dichloroisonicotinic acid (INA) and its methylester derivatives (Kuc, 1995).
Chemical inducers of disease resistance hold substantial promise as agents of plant disease control (Ye et al 1995).

The present work aimed to study the ability of some biotic and abiotic agents alone or in combination to suppression of bacterial angular leaf spot disease of cucumber, under greenhouse and commercial plastic house conditions.

\section{MATERIAL AND METHODS}

\section{The pathogen}

Virulent isolate of $P$. syringae pv. lachrymans was isolated and identified from infected cucumber plants (Abd ElGhafar, 2000). The bacterium was grown on yeast extract peptone agar (YDC) medium for $48 \mathrm{~h}$ at $28 \mathrm{C}^{\circ}$. Bacterial growth was suspended in sterile distilled water (SDW) and adjusted according its optical density at $\mathrm{A} 620 \mathrm{~nm}=0.1\left(10^{7}\right.$ colony forming units (cfu)/ml) according to ElSadek et al (1992) and Abd El-Ghafar (2000).

\section{Seeds and sowing}

Fungicides- free seeds of cucumber cultivar Beet Alfa MR were obtained from Department of vegetable, Horticulture Research Institute, Agriculture Research center, Giza, Egypt and sown in seedling trays containing pasteurized peat moss and vermiculite $(2: 1 \mathrm{v} / \mathrm{v})$. Trays were kept under greenhouse condition and irrigated regularly. Cucumber seedlings (3- week- old) were transplanted into clay pots $(20 \mathrm{~cm}$ diameter) containing sandy- clay soil and each pot contained three seedlings. 


\section{Bioagents}

Isolates of B. subtilis (Bs3), P. aeruginosa (Pa1), P. fluorescens (Pf5) and $P$. putida (Pp12) were obtained from bacterial disease laboratory, Department of plant pathology, Faculty of Agriculture, Ain Shams University, Cairo, Egypt. These isolates were previously evaluated as bio-control agents against phytopathogenic bacteria (Abd El-Ghafar and Abd El-Sayed 1997, Abd El-Ghafar, 2000, Abd El-Ghafar and Mosa, 2001 and Abd El-Sayed et al 2003). These isolates were grown on yeast extract peptone dextrose agar medium for $48 \mathrm{hr}$ at $28 \mathrm{C}^{\circ}$. The bacterial cells suspended in distilled water and centrifuged at $3000 \mathrm{rpm}$ for 30 min. The precipitant was re-suspended in distilled water to reach concentration of $10^{8} \mathrm{cfu} / \mathrm{ml}$ as determined from a standard curve based on absorbance at A620 nm.

Bio-agents were used as soil drench or foliar treatments. The seedlings were treated (soil drench as soil treatment or sprayed as foliar treatment) with bioagents $(10 \mathrm{ml} /$ seedling) after 2 - week from sowing trays and after 3 - week from transplanting to clay pots. Untreated seedlings with bio-agents were also planted in clay pots. Treated and untreated seedlings were inoculated with bacterial suspension $(10 \mathrm{ml} /$ seedlings $)$ of the pathogen after 4-week from transplanting to clay pots. Five pots were used as replicates per treatment. All inoculated seedlings with the pathogen were placed in humidity chamber for 48-h before and after inoculation, (Abd El-Ghafar and Mosa, 2001).

\begin{abstract}
Abiotic agents
Bion (benzol 1,2,3 siodiazol,7 carbo synobic acid-s-methy ester) or Ethephone (2-chloro ethyl phosphonic acid) or Gasmonic acid (alpha-linolenic acid) or Salicylic acid (2- hydroxybenzoic acid, C7H603) were applied as abiotic agents at $0.25,0.50,0.75$ and $0.1 \%$ or $2.5 ; 5$; 7.5 and $10 \mathrm{ppm}$ or $0.25,0.5,0.75$ an $0.1 \%$ or $2.5,5,7.5$ and $10 \mathrm{mM}$, respectively. These agents were used as seed soaking or foliar treatment. In case of seed treatment, seed of cucumber were soaked in abiotic agents solutions for $6 \mathrm{~h}$ before planting in seedling trays. In cause of foliar treatment, cucumber seedlings were sprayed with abiotic agents (10 $\mathrm{ml} /$ seedling) after 2-week from sowing into seedling trays and after 3-week from transplanting in clay pots. Untreated seedlings with abiotic agents were also planted in clay pots. Treated and untreated seedlings were inoculated with bacterial suspension $(10 \mathrm{ml} /$ seedling $)$ of the pathogen after 4-weeks from transplanting in clay pots. Five pots were used as replicates per treatment. All inoculated seedling with the pathogen were placed in humidity chamber for 48-h before and after inoculation (Abd El-Sayed et al 1996).
\end{abstract}

\section{Integration treatments}

\section{Greenhouse experiments}

Seedlings of cucumber were treated with bio-agents ( $P$. fluorescens (Pf5) and $P$. putida (PP12) as soil drench treatment after 2-week from sowing into seedling trays, as mentioned previously. Treated 
seedlings with bio-agents were retreated with abiotic agents (ethephone, at 7.5 ppm and salicylic acid, at $7.5 \mathrm{mM}$ ) as foliar treatment after 3-week from transplanting in clay pots, as mentioned before. Untreated seedlings were also planted in clay pots. Treated and untreated seedlings were inoculated with the pathogen as mentioned previously. All inoculated seedlings were placed in humidity chamber for 48-h before and after inoculation (Abd El-Ghafar and Mosa, 2001). Five pots were used as replicates per treatment.

\section{Commercial plastic house experiments}

These experiments were carried out under commercial plastic house conditions, at Bhateem Research station, Agriculture Research center, during 20032005 growing seasons. The experiment design was a randomized complete block. Five rows of plants were applied per treatment and each row contained 50 plants. Generally five rows were left without treatment as control. All plants were left for naturally infection. During the growing season, conventional cultural practices were followed as recommended for irrigation and fertilizer treatments. Cucumber seedlings were treated as soil treatment with bio-agents in seedlings trays as mentioned previously through greenhouse experiment. Treated seedlings with bio-agents were planted in commercial plastic house and retreated as foliar treatment with abiotic agents as mentioned before through greenhouse experiment (Abd El-Ghafr and Mosa, 2001).

\section{Disease assessment}

In greenhouse experiments, disease incidence was recorded after 7 days from inoculation with the pathogen on 15 plants per treatment. In commercial plastic house experiments, disease incidence was recorded on 50 plants per treatment (10 plants/ row) after 4- week from planting. Disease severity was estimated as mean number of spots per leaf, where four leaves were randomly selected from each plant, and as disease index (\%) according to the disease rating scale from o to 5 , in which $o=$ no lesion, $1=1-20 \%$ of leaf area with lesion, $2=21-40 \%, 3=41-$ $60 \%, 4=61-80 \%$ and $5=81-100 \%$ (Liu et al1995 and Raupach and Kloepper, 1998). Disease index (DI) was calculated by the following formula:

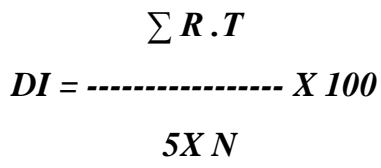

Where, $\mathrm{T}=$ Total number of plants with each category.

$\mathrm{R}=$ Disease severity scale $\mathrm{R}(\mathrm{R}=$ $0,1,2,3,4$ and 5).

$\mathrm{N}=$ Total number of plants tested.

Also, percentage of disease reduction (PDR) was calculated as the following:

$$
P D R=\frac{D s_{c k}-D s_{t r} x 100}{D s_{c k}} \times 100
$$

Where, $\mathrm{Ds}_{\mathrm{ck}}=$ Disease severity in check treatment

$\mathrm{Ds}_{\mathrm{tr}}=$ Disease severity in treated treatment

Data were statistically analyzed using the "F" test and the value of LSD ( $p=$ 
0.05) was calculated (Snedecor and Cochran, 1967).

\section{RESULTS}

Effect of bio- and abiotic agents on disease severity

Results in Table (1) showed that application of B. subtilis, $P$. aeruginosa, $P$. fluorescens and P. putida isolates as biotic agents led to considerable decrease in severity of bacterial angular leaf spot disease of cucumber compared with the control. Fluorescent pseudomonads $(P$. aeruginosa, $P$. fluorescens and $P$. putida) isolates were more effective to reduce the disease than isolate of $B$. subilis, when they were applied as soil treatment. Meanwhile, application of $B$. subtilis isolate as foliar treatment was more effect than fluorescent pseudomonads isolates. Meantime, isolates of $P$. fluorescens and $P$. putida were the most effective against severity of cucumber bacterial angular leaf spot disease. However, application of Bion, ethephone, gasmonic acid and salicylic acid as abiotic agents reduced severity of bacterial angular leaf spot disease compared with the control. Application of abiotic agents as foliar treatment was more effective to decrease the disease severity than application of these agents as seed treatment. Meanwhile, disease severity was significantly reduced by increasing rates of abiotic agents. Salicylic acid and ethephone were the most effective against severity of bacterial angular leaf spot disease of cucumber (Fig.1 and 2)

\section{Effect of combination between bio- and abiotic agents on disease severity}

Interaction between bioagents ( $P . f l u$ orescens or $P$. putida isolates) as soil treatment and abiotic agent (Salicylic acid or ethephone) as foliar treatment greatly decrease severity of bacterial angular leaf spot disease of cucumber, under greenhouse and commercial plastic house conditions, compared with the control. Disease severity was more reduced under greenhouse condition than under commercial plastic house condition, where percentage of disease reduction ranged from 36.2 to $44.7 \%$ and ranged from 23.9 to $32.5 \%$, respectively. Combination between $P$. fluorescens as soil treatment and abiotic agents as foliar treatment were more effective against the disease severity than combination between $P$. putida as soil treatment and abiotic agents as foliar treatment. Meanwhile, combination between $P$. fluorescens as bioagent (soil treatment) and salicylic acid as abiotic agent (foliar treatment) were the most effective against severity of bacterial angular leaf spot disease of cucumber under greenhouse and commercial plastic house conditions (Table 2 and 3 ).

\section{DISCUSSION}

Bacterial angular leaf spot disease of cucumber caused by $P$. syringae pv. lachrymans has become an important disease under commercial plastic house conditions in Egypt (El-Sadek et al 1992 and Abd El-Ghafar, 2000). Application of biotic and abiotic treatments alone decreased the disease severity compared 
Table 1. Influence of bio-agents as soil and foliar treatments on severity of bacterial angular leaf spot disease of cucumber, under greenhouse conditions

\begin{tabular}{|ccccc|}
\hline Bio-agent & Treatment & $\begin{array}{c}\text { Mean No. of } \\
\text { Spot/Leaf }\end{array}$ & $\begin{array}{c}\text { Disease } \\
\text { index } \%\end{array}$ & $\begin{array}{c}\text { Disease } \\
\text { reduction } \\
\%\end{array}$ \\
\hline Bacillus subtilis & Soil & 7.5 & 39.9 & 17.9 \\
(Bs3) & Foliar & 8.3 & 43 & 12.6 \\
Pseudomonas aeruginosa & Soil & 7 & 35.3 & 27.4 \\
(Pa1) & Foliar & 8.8 & 45.6 & 7.3 \\
Pseudomonas fluorescens & Soil & 6.2 & 30.445 & 37.5 \\
(Pf5) & Foliar & 8.6 & 45 & 8.5 \\
Pseudomonas putida & Soil & 6.5 & 32.6 & 32.9 \\
(Pp12) & Foliar & 8.7 & 45.4 & 7.7 \\
Check & Soil & 8.9 & 48.6 & 0 \\
& Foliar & 9.3 & 49.2 & 0 \\
\hline
\end{tabular}

LSD at $5 \%$

$\begin{array}{lll}\text { Bio-agent } & 0.3 & 2.6 \\ \text { Treatment } & 0.7 & 3.2 \\ \text { Interaction } & 1.3 & 3.5\end{array}$

with the control. Biotic agents (fluorescent pseudomonads, i.e. $P$. aeruginosa, $P$. fluorescens and $P$. putida isolates) as soil drench treatment and abiotic agents (Salicylic acid and ethephone) as foliar treatment were the most effectiveness against severity of bacterial angular leaf spot of cucumber under greenhouse conditions. Results of the present study are in agreement with Liu et al (1995); Wei et al (1996); Kloepper et al (1996); Lucase (1998); Abd El-Ghafar (2000) and Abd El-Ghafar and Mosa (2001) that application of PGPR strains to root may induce systemic resistance to foliar disease. Severity of bacterial angular leaf spot disease of cucumber was significantly reduced, when isolates of bio agents were applied as soil treatment (Abd ElGhafar, 2000). Induced systemic resistance (ISR) is based on plant defense mechanism that are activates by inducing agent as PGPR (Klopper et al 1992) or ISR once expressed activity multiple potential defense mechanisms that include increasing in activity of several defense enzymes and pathogenesis- related (PR) proteins (Lawton and Lamb, 1987 and Strobel et al 1996) and phytoalexins (Kuc and Rush, 1985, Ongena et al 2000 and Jeun et al 2004). Plant growthpromoting rhizobacteria (PGPR) are root colonizing beneficial bacteria and the beneficial effects include biological control and growth promotion (Weller, 1988). 

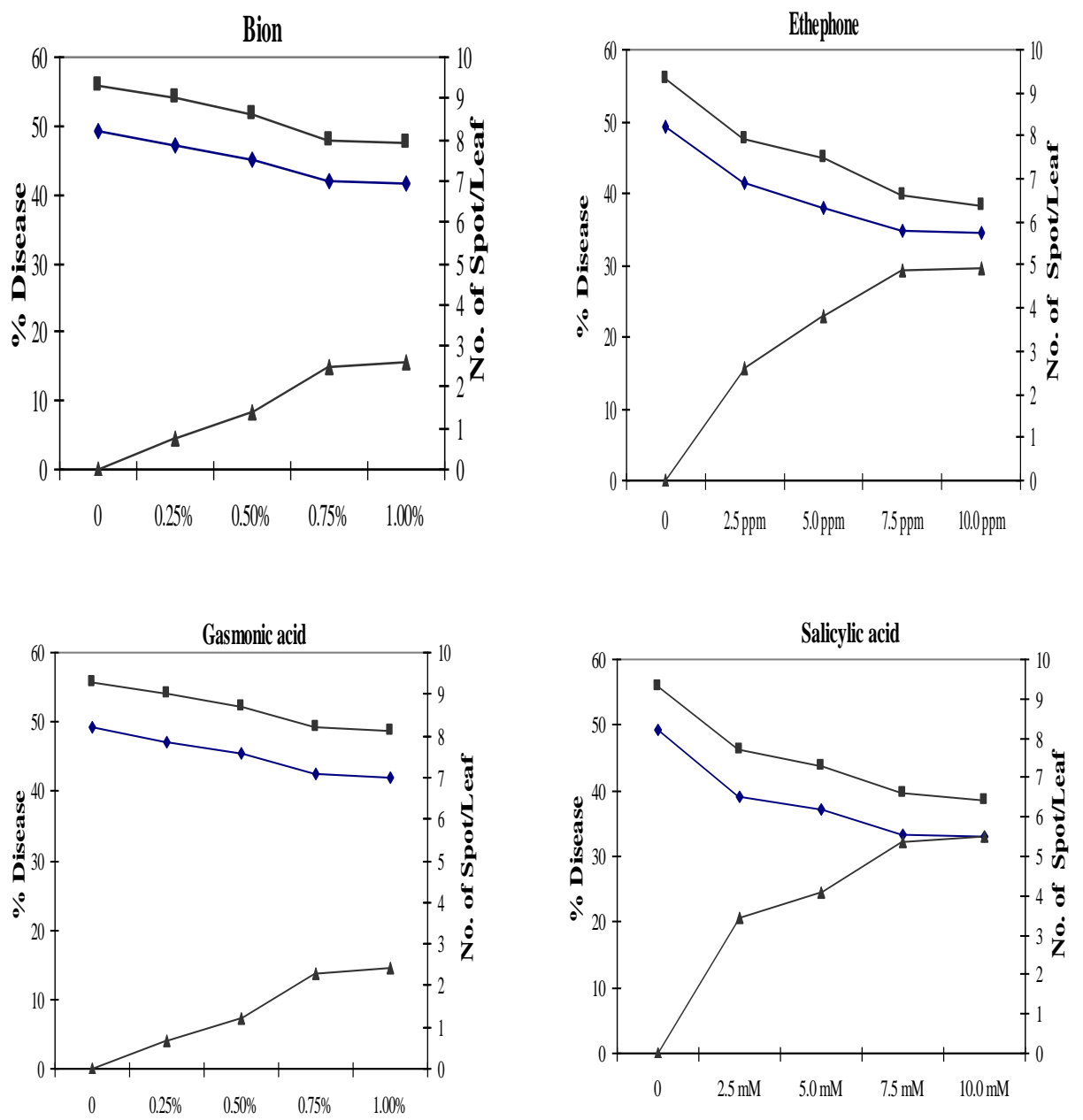

$\rightarrow$ Disease index \% $\rightarrow$-Disease reduction \% $\rightarrow-$ Mean No. of Spot/Leaf

Fig. 1. Effect of abiotic agents, at different rates as foliar treatment on severity of bacterial angular leaf spot disease of cucumber, under greenhouse conditions 

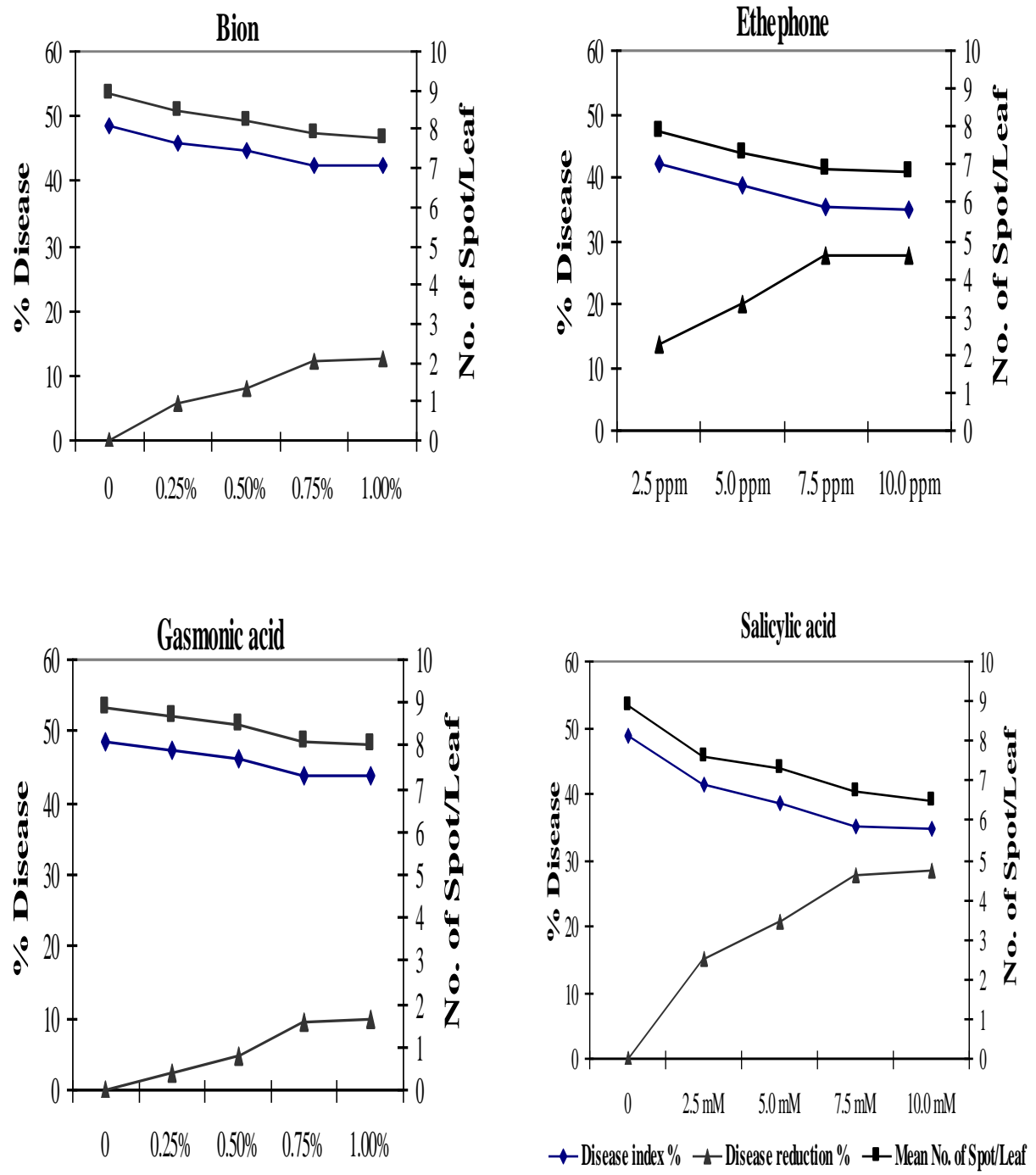

Fig 2. Effect of abiotic agents, at different rates as seed treatment on severity of bacterial angular leaf spot disease of cucumber, under greenhouse conditions 
Table 2. Influence of combination between bio-agents as soil treatment and abiotic agents as foliar treatment on severity of bacterial angular leaf spot disease of cucumber, under greenhouse conditions

\begin{tabular}{|c|c|c|c|c|}
\hline Soil treatment & Foliar treatment & $\begin{array}{l}\text { Mean No. of } \\
\text { Spot/Leaf }\end{array}$ & $\begin{array}{l}\text { Disease } \\
\text { index \% }\end{array}$ & $\begin{array}{c}\text { Disease } \\
\text { reduction \% }\end{array}$ \\
\hline \multirow{3}{*}{$\begin{array}{c}\text { Pseudomonas } \\
\text { fluorescens (Pf5) }\end{array}$} & Ethephone (7.5 ppm) & 5.9 & 29.7 & 39.6 \\
\hline & Salicylic acid (7.5 mM) & 5.6 & 27.2 & 44.7 \\
\hline & None & 6.2 & 30.4 & 38.2 \\
\hline \multirow{3}{*}{$\begin{array}{l}\text { Pseudomonas } \\
\text { putida (Pp12) }\end{array}$} & Ethephone (7.5 ppm) & 6.1 & 31.4 & 36.2 \\
\hline & Salicylic acid (7.5 mM) & 5.9 & 30.6 & 37.8 \\
\hline & None & 6.5 & 32.6 & 33.7 \\
\hline \multirow{3}{*}{ None } & Ethephone (7.5 ppm) & 6.6 & 34.8 & 29.3 \\
\hline & Salicylic acid (7.5 mM) & 6.6 & 33.3 & 32.3 \\
\hline & None & 9.3 & 49.2 & 0.0 \\
\hline \multicolumn{5}{|l|}{ LSD at $5 \%$} \\
\hline & Soil & 1.0 & & \\
\hline & Foliar & 1.3 & & \\
\hline & Interaction & 1.8 & & \\
\hline
\end{tabular}

Table 3. Influence of combination between bio-agents as soil treatment and abiotic agents as foliar treatment on severity of bacterial angular leaf spot disease of cucumber, under commercial plastic house conditions

\begin{tabular}{|c|c|c|c|c|}
\hline Soil treatment & Foliar treatment & $\begin{array}{c}\text { Mean No. of } \\
\text { Spot/Leaf }\end{array}$ & $\begin{array}{l}\text { Disease } \\
\text { index \% }\end{array}$ & $\begin{array}{c}\text { Disease } \\
\text { reduction \% }\end{array}$ \\
\hline \multirow{3}{*}{$\begin{array}{c}\text { Pseudomonas } \\
\text { fluorescens (Pf5) }\end{array}$} & Ethephone (7.5 ppm) & 4.3 & 15.0 & 28.2 \\
\hline & Salicylic acid (7.5mM) & 4.0 & 14.1 & 32.5 \\
\hline & None & 4.8 & 16.7 & 20.1 \\
\hline \multirow{3}{*}{$\begin{array}{l}\text { Pseudomonas } \\
\text { putida (Pp12) }\end{array}$} & Ethephone (7.5 ppm) & 4.6 & 15.9 & 23.9 \\
\hline & Salicylic acid $(7.5 \mathrm{mM})$ & 4.2 & 14.8 & 29.2 \\
\hline & None & 5.0 & 17.6 & 15.8 \\
\hline \multirow{3}{*}{ None } & Ethephone (7.5 ppm) & 4.8 & 16.9 & 19.1 \\
\hline & Salicylic acid (7.5 mM) & 4.5 & 16.0 & 23.4 \\
\hline & None & 5.8 & 20.9 & 0.0 \\
\hline \multicolumn{5}{|l|}{ LSD at $5 \%$} \\
\hline & 0.2 & 0.5 & & \\
\hline & Foliar & 0.3 & & \\
\hline & Interaction & 0.9 & & \\
\hline
\end{tabular}

Arab Univ. J. Agric. Sci., 14(1), 2006 
The effect of salicylic acid (SA) or its derivatives on inducing resistance in plants against pathogens was reported by Malamy and Klessing (1992) who stated that the effect of the SA was not caused by direct action on the growth of pathogens, but the effect of SA application was rather a consequence of induction of plant defense response. Many biochemical and soil changes occur during ISR i.e. pathogenesis- related (PR) proteins. Acidic PRproteins including acidic $\beta 1$, 3 -glucanase and chitinase are secreted intercellular space, where they would be en-counted and act against fungal and/or bacterial pathogens, at an early stage of infection process. Basic $\beta 1,3$-glucanase and chitinase accumulate in the vacuole, may interact with pathogens, at a later stage of infection, during host cell deterioration (Ye et al 1995 and Kuc, 1995). Meuwly et al (1995) showed that SA is an essential component in the signal transduction pathway leading to systemic acquired resistance (SAR) is synthesized from phenylalanine (phe) and benzoic acide in cucumber plants inoculated with $P$. syringae pv. lachrymans. Abd El-Sayed et al (1996) and Zayed et al (2004) mentioned that application of abiotic agents i.e. salicylic acid or aspirin or Bion have been used successfully as resistance inducer for controlling bacterial wilt of solanaceous.

The results from greenhouse and commercial plastic house experiments conducted over 2- year period clearly revealed that combining bioagents $(P$. fluorescens or $P$. putida isolates) as soil treatment and abiotic agents (salicylic acid or ethephone) as foliar treatment was highly effective for controlling bacterial angular leaf spot disease of cucumber than either treatments alone. Meanwhile, combination between $P$. fluorescens as soil treatment and salicylic acid as foliar treatment was most effectiveness against the disease severity. Thus, the results indicated that both fluorescens pseudomonads isolates as bioagents and salicylic acid or ethephone as abiotic agents hold promise for practical disease control. These may be possible to apply a combination of both to enhance their activity and to reduce number of foliar sprays with abiotic agents or bactericides. These results will be of economic importance and applicable in an integrated disease management strategies for cucumber crop.

\section{REFERENCE}

Abd El-Ghafar, N.Y. (2000). Biocontrol of bacterial angular leaf spot disease of cucumber. $8^{\text {th }}$ Conf. Agric. Dev. Res., Annals Agric. Sci., Cairo, Sp. Issue 4: 1437-1450.

Abd El-Ghafar, N.Y. and A.A. Mosa (2001). Integration between biological and chemical treatments to control bacterial spot disease of tomato. Egypt. J. Phytpathol. 29: 33-45.

Abd El-Ghafar, N.Y. and Abd ElSayed, Wafaa, M. (1997). Biological control of bacterial soft rot of potato. Arab Univ. J. Agric. Sci., Ain Shams Univ., Cairo 5: 419-431.

Abd El-Sayed, Wafaa, M.; N.Y. Abd El-Ghafar and S.A.M. Shehata (1996). Application of salicylic acid and aspirin for inducton of resistance to tomato plants against bacterial wilt and its effect on endogenus hormones. Annals Agric. Sci., Ain Shams Univ., Cairo, 41: 10071020.

Abd El-Sayed, Wafaa M.; R.A. Bayoumi and N.Y. Abd El- Ghafar (2003). 
Biological control of potato bacterial wilt disease under Egyption conditions. Annals Agric. Sci., Ain Shams Univ., Cairo 48: 353- 364.

Dixon, G.R. (1981). Vegetable Crop Diseases. First Published by the Scientific and Medical Division, pp. 307-310, The Macmillan Press Ltd., London.

El-Sadek, S.A.M.; M.R. Abd El-Latif; T.I. Abd El-Gawad and N.A. Hussein (1992). Occurrence of angular leaf spot disease in greenhouse cucumber in Egypt. Egypt. J. Microbiol. 27: 157-175.

Jeun, Y.C.; K.S. Pack; C.H. Kim; W.D. Fowler and J.W. Kloepper (2004). Cytological observation of cucumber plants during induced resistance elicited by rhizobacteria. Biological Control 29: 34-42.

Kloepper, J.W.; S.D. Tuzun and J. Kuc (1992). Proposed definitions related to induced disease resistance. Biocontrol Sci. Technol. 2: 349- 351.

Kloepper, J.W.; G.W. Zehner; S.D. Tuzun; J.F. Murphy; G. Wei; C. Yao and G.S. Raupach (1996). Toward agricultural implementation of PGPR- mediated induced systemic resistance against crop pests. pp. 165- 174. In: Advances in Biological Control of Plant Disease. (Wehuau, T.; J. Cook and A. Roviar, eds.), China Agriculture University Press, Beijing.

Kuc, J. (1987). Plant Immunization and Its Applicability for Disease Control. pp. 255-274. Chet I. ed., John Wiley and Sons, New York .

Kuc, J. (1995). Induction Systemic Resistance. An Overview. pp. 169-175. Kluwer Academic Publishers, Netherlands.

Kuc, J. and J.S. Rush (1985). Phytoalexins. Arch. Biochem. Biophys. 236: 455- 472.
Kuc, J. and N.E. Strobel (1992). Induced resistance using pathogens and non-pathogens. In: Biological Control of Plant Disease, Progress and Challenges for the Further. pp. 295-327.(Tjamos, E.C.; G.S. Papavizas and R.J. Cook, eds) Plenum Press, New York.

Lawton, M.A. and C.J. Lamb (1987). Transcriptional activation of plant defense genes by fungal elicitor, wounding and infection. Mol. Cell. Biol. 7: 335341.

Liao, C.H. (1989). Antagonism of Pseudomonas putida strain PP22 to phytopathogenic bacteria and its potential use as a biocontrol agent. Plant Disease 73: 223-226.

Liu, L.; J.W. Kloepper and S. Tuzun (1995). Induction of systemic resistance in cucumber against bacterial angular leaf spot by plant growth-promoting rhizobacteria. Phytopathology 85: 843-847.

Lucase, J.A. (1998). Biological control of plant disease. pp. 233-248, In: Plant Pathology and Plant Pathogens (Lucase, J. A; ed), Blackwell Science, London.

Madamanchi, N.R. and J. Kuc (1991). Induced resistance in plants. In: Fungal Spores and Disease Intitation in Plants and Animals. pp. 347-376. (Cole, G.T. and H.C. Hoch, eds.) Plenum Press, New York.

Malamy, J. and D.F. Klessing (1992). Salicylic acid and plant disease resistance. Plant J. 2: 643- 645.

Mei, R.; B. Chen; S. Lu and Y. Chen (1990). Field application of yield increasing bacteria (YIB). Chin. J. Micro. Ecol. 2: 45-49.

Meuwly, P.; W. Molders; A. Buchala and J.P. Metraux. (1995). Local and systemic biosynthesis of salicylic acid in infected cucumber plants. Plant Physiol. 109: 1107-1114. 
Ongena, M.; F. Daayf; P. Jacques; P. Thonart; N. Benhamou; T.C. Paulitz and P.R. Belange (2000). Systemic induction of phytoalexins in cucumber in response to treatments with fluorescent pseudomonads. Plant Pathol. 49: 523530.

Palleroni, N.J. (1984). Family: Pseudomonaceae, Wilson, Broadhurst, Buchanan, Krumwide, Rogers and Smith 1917, In: Bergeys Manual of Systematic Bacteriology, Vol. I, pp. 143-213, Krieg, N. R. and K. G. Holt,eds. Williams and Wilkins, Baltimore, M. D.

Rasmussen, J.B.; R. Hammerschmidt and M.N. Zook (1991). Systemic induction of salicylic acid accumulation in cucumber after inoculation with Pseudomonas syringae pv. syringae. Plant Physiol. 97: 1342- 1347.

Raupach, G.S. and J.W. Kloepper (1998). Mixtures of plant growthpromoting rhizobacteria enhance biological control of multiple cucumber pathogens. Phytopathology 88: 1158-1164.

Raupach, G.S. and J.W. Kloepper (2000). Bio-control of cucumber disease in the faeld by plant growth-promoting rhizobacteria with and without methyl bromide fumigation. Plant Disease 84:1073-1075.

Schroth, M.N.; J.E. Loper and D.C. Hildebrand (1984). Bacteria as biocontrol agent: of plant disease. pp. 362-369. In: Current Perspectives in Microbial Ecology. Klug, M.J. and C.A. Reddy, eds. American Society for Microbiology, Washington, D.C.

Snedecor, G.W. and W.G. Cochran (1967). Statistical Methods (2 ${ }^{\text {nd }}$ Ed.). Iowa State Univ. Press, Ames, Iowa, USA.
Strobel, N.E.; C. Ji.; S. Goplalan; J. Kuc and S.Y. He (1996). Induction of systemic acquired resistance in cucumber by Pseudomonas syringae pr. Syringae 61 Hrpzpss protein. Plant J. 9: 431- 439.

Van Loon L.C. and J.F. Antoniw (1982). Comparison of the effect of salicylic acid and ethephone with virusinduced hypersensitivity and acquired resistance in tobacco. Neth. J. Plant Pathol. 88:643-654.

Wei, G.; J.W. Kloepper and S. Tuzen (1996). Induced systemic resistance to cucumber disease and increased plant growth by plant growth- promoting rhizobacteria under field conditions. Phytopathology 86: 221- 224.

Weller, D.M. (1988). Biological control of soil borne plant pathogens in the rhizosphere with bacteria. Annual Rev. Phytopathol. 26: 379- 407.

Ye, X.S.; S.Q. Pan and J. Kuc (1989). Pathogenesis-related proteins and systemic resistsnce to TMV and blue mold induced by tobacco mosaic virus, Peronospora tabacina and aspirin. Physiol. Mol. Plant Pathol. 35: 161- 175.

Ye, X.S.; N.E. Sterobel and J. Kuc (1995). Induced systemic resistance (ISR): Activation of natural defense mechanisms for plant disease control as part of integrated pest management (IPM). Noval Approaches to IPM, Chapter 5 pp. 95-113.

Zayed, K.A.M.; N.Y. Abd El-Ghafar; I.H. El-Abbasi; and F.M. Abo ElAbbas (2004). Integration between abiotic and biotic agents to control potato bacterial wilt disease. Arab Univ. J. Agric. Sci., Ain Shams Univ., Cairo 12: 447457. 


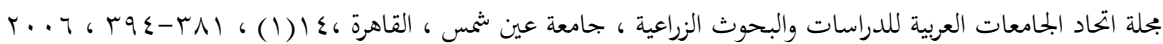

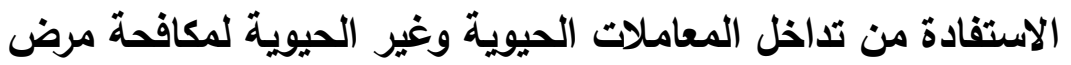

التبقع البكتيري الزاوي في الخيار

[ro]

وفاء محمد عبد السبد' - عماد الدين علي مصطفي جادو' - ناجي يسين عبد الغفار' 1 - قسم أمراض النبات - كلية الزراعة- جامعة عين شمس - شبرا الخيمة- القاهرة- مصر

Pseudomonas fluorescens and P. putida فاعلية أكثر في مكافحة المرض. ولقد وجد

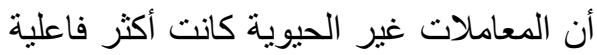
في مكافحة المرض عند استخدامها كمعاملة رش علي المجموع الخضري من استخدامها كمعاملة بذرة. تزداد فاعلية المعاملات غير الحيوية في مكافحة المرض كلما زاد معدل

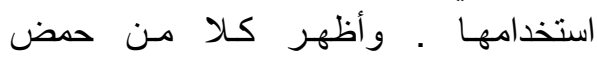
الساليسليك و الاثيفون فاعلية أكبر في مكافحة

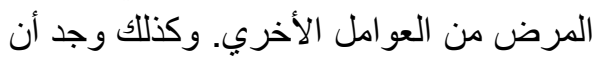

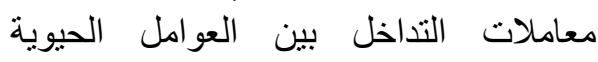
(Pseudomonas fluorescens or P. putida) كمعاملة تربة و العوامل غير الحيوية (حمض كلية الساليسليك أوالاثيفون) كمعاملة رش وش علي المجموع الخضري أظهرت نتائج مشجعة بدرجة كبيرة في مكافحة المرض مقارنة بمعاملة المقارنة. ورجة وبد أن التداخل بين بكتريا بseudomonas fluorescens بكامل حيوي وكمعاملة تربة وحمض الساليسليك كعامل غير حيـوي وكمعاملة رش وشي علي المجموع الخضري كانت الأكثر فاعلية في

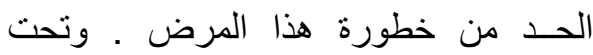

زاد انتشـار مـرض التبقع البكتيري الزاوي في الخيـار تحت نظم الزراعة المحمية مما سبب مشاكل كثيرة للمزارعين في مناطق زراعـة الخيار تحت الظروف المصرية. وقد أجريت هذة الدراسة بغرض تقييم فاعلية التداخل بين المعاملات الحيوية و غير الحيوية في مكافحة هذا المرض تحت فيه لتهن

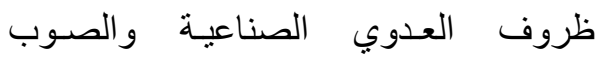

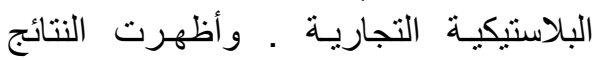
المتحصل عليهـا أنه تحت ظروف البه العدوي الصناعية المعاملات الحيوية وغير الحيوية

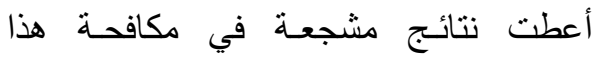
المرض بالمقارنة مع معاملة المقارنة. ووجد أن البكتريا الفلورسنتية ( Pseudomonas) aeruginosa, P. fluorescens and P. putida Sacillus كانت أكثر فاعليـة مـن بكتريـا subtilis كمعاملة ري للتربة في حين أن جميع العوامل الحيوية المختبرة كانت أكثر فاعلية في مكافحة المرض عندما استخدمت كمعاملة تربة من استخدامها كمعاملة رش عل علي

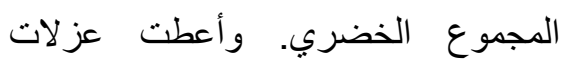




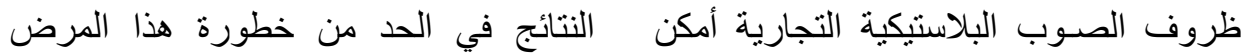

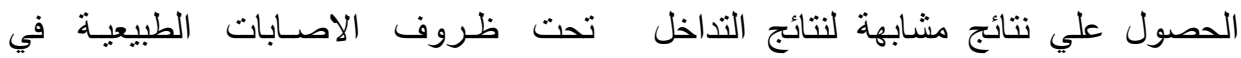

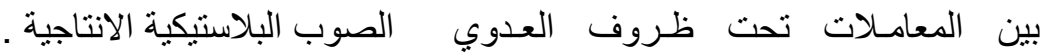
الصناعية ولذلك من الممكن الاستفادة من تلك

تحكيم: أ.د سعـاد محمد عبد الله

أ.د موريس صبرى ميخائيل 